\title{
Jugular Foramen's Paraganglioma in a Patient with Von Hippel-Lindau Disease: Case Report
}

\section{Paraganglioma do forame jugular em paciente com doença de Von Hippel-Lindau: Relato de caso}

\author{
Barbara Casalecchi Pereira ${ }^{1}$ Julia Dallana Aznar ${ }^{10}$ Amélia Limongi Zambon ${ }^{10}$ \\ Diogo Fabricio Coelho de Melo ${ }^{20}$ Marcelo Nery Silva ${ }^{3(0)}$
}

1 Universidade Municipal de São Caetano do Sul, São Paulo, SP, Brazil
2 Hospital Heliópolis, São Paulo, SP, Brazil
${ }^{3}$ Neurosurgery Service, Hospital Heliópolis, São Paulo, SP, Brazil

Arq Bras Neurocir 2021;40(2):e200-e206.
Address for correspondence Barbara Casalecchi Pereira, MS, Universidade Municipal de São Caetano do Sul, Rua Pantojo, 488, 72, Vila Regente Feijó, São Paulo, SP, 03343-000, Brazil (e-mail: barbaracasalecchi@hotmail.com).

\begin{abstract}
Keywords

- glomus

- parangliomas

- von hippel-lindau
\end{abstract}

Resumo
Glomus jugular tumors, also known as paragangliomas (PGLs), are rare and related to several clinical syndromes described. These are located in the carotid body, the jugular glomus, the tympanic glomus and the vagal glomus. The symptoms are directly related to the site of involvement and infiltration. These lesions have slow growth, are generally benign and hypervascularized, have a peak incidence between the age of 30 to 50 years old; however, when associated with hereditary syndromes, they tend to occur a decade earlier. Several familial hereditary syndromes are associated with PGLs, including Von HippelLindau disease $(\mathrm{VHL})$ in $<10 \%$ of the cases. The diagnosis and staging of PGLs are based on imaging and functional exams (bone window computed tomography [CT] with a "ground moth" pattern and magnetic resonance imaging (MRI) with a "salt and pepper" pattern). The cerebral angiography is a prerequisite in patients with extremely vascularized lesions, whose preoperative embolization is necessary. The histopathological finding of cell clusters called "Zellballen" is a characteristic of PGLs. Regarding the jugular foramen, the combination of two or three surgical approaches may be necessary: (1) lateral group, approaches through the mastoid; (2) posterior group, through the retrosigmoid access and its variants; and (3) anterior group, centered on the tympanic and petrous bone. In the present paper, we report a case of PGL of the jugular foramen operated on a young female patient who underwent a surgery with a diagnosis of Von Hippel-Lindau Disease (VHL) at the Neurosurgery Service of the Hospital Heliópolis, São Paulo, state of São Paulo, Brazil in 2018 , by the lateral and posterior combined route.

Os tumores do glomus jugular, conhecido também como paragangliomas (PGLs), são raros e se correlacionam com várias síndromes clínicas descritas. Estes localizam-se no received

May 11,2020

accepted

August 24, 2020

published online

November 26, 2020
DOI https://doi.org/ 10.1055/s-0040-1719002. ISSN 0103-5355.

\footnotetext{
(c) 2020. Sociedade Brasileira de Neurocirurgia. All rights reserved. This is an open access article published by Thieme under the terms of the Creative Commons Attribution-NonDerivative-NonCommercial-License, permitting copying and reproduction so long as the original work is given appropriate credit. Contents may not be used for commercial purposes, or adapted, remixed, transformed or built upon. (https://creativecommons.org/ licenses/by-nc-nd/4.0/) Thieme Revinter Publicações Ltda., Rua do Matoso 170, Rio de Janeiro, RJ, CEP 20270-135, Brazil
} 
Palavras-chave

- glomus

- parangliomas

- von hippel-lindau corpo carotídeo, na veia jugular, no ouvido médio e no corpo vagal. Os sintomas são diretamente relacionados ao sítio de envolvimento e infiltração. Essas lesões têm crescimento lento, geralmente são benignos e hipervascularizados, têm pico de incidência entre 30 e 50 anos de idade; contudo, quando associados a síndromes hereditárias, tendem a ocorrer uma década mais cedo. Várias síndromes hereditárias familiares estão associadas aos PGLs, dentre elas a Doença de Von Hippel-Lindau (VHL) em $<10 \%$ dos casos. O diagnóstico e estadiamento dos PGLs assentam-se na realização de exames imaginológicos e funcionais (tomografia computadorizada [TC] da janela óssea com padrão "traça moída" e ressonância magnética [RM] com padrão "sal e pimenta") e angiografia cerebral como pré-requisito em pacientes com lesões extremamente vascularizadas, cuja embolização pré-operatória é necessária. O achado histopatológico de aglomerados celulares denominados "Zellballen" é característico dos PGLs. Em relação ao forame jugular, a combinação de dois ou três acessos cirúrgicos pode ser necessária: (1) grupo lateral, abordagens através da mastoide; (2) grupo posterior, através do acesso retrossigmóide e suas variantes; e (3) grupo anterior, centrado no osso timpânico e petroso. No presente trabalho, relatamos um caso de PGL do forame jugular em paciente jovem do sexo feminino operada com diagnóstico de Doença de Von Hippel-Lindau (VHL) no serviço de neurocirurgia do Hospital Heliópolis, São Paulo, SP, Brasil, em 2018 por via combinada lateral e posterior.

\section{Introduction}

Tumors of the foramen jugular (FJ) are rare, in most cases benign, and present great difficulty in surgical treatment because of the involvement of important vascular and nervous structures. ${ }^{1}$

Several tumors can affect this region; among the most common are paragangliomas (PGLs) (most frequent), Schwannomas and meningiomas. Paragangliomas - also called cheemoderms, glomus tumor, chemiodectoma, glomerocytoma, tumor of the tympanic body and receptoma ${ }^{2}$-are benign neuroendocrine neoplasms originated from neural crest derivatives, the sympathetic and parasympathetic extra-adrenal paraganglia (glomus bodies). ${ }^{3}$

Malignant tumors can also affect the FJ, including metastasis (carcinomas), chondrosarcomas, and chondromas as part of the differential diagnosis of these lesions. ${ }^{4}$

Glomus jugular tumors are rare and commonly grouped as tumors of the skull base. The incidence of these tumors is $\sim 0,07$ per 100,000 per year, ${ }^{5}$ varying in some authors from 1 per $30,000 .^{6}$ These tumors arise within the JF (pars venous), with a peak incidence between the age of 30 to 50 years old; ${ }^{7}$ however, when associated with hereditary syndromes, they tend to occur a decade earlier. ${ }^{8}$ They become symptomatic in the $5^{\text {th }}$ and $6^{\text {th }}$ decades of life; women are 3 to 6 times more affected than men. These tumors grow slowly (growth rate is $\sim 1 \mathrm{~mm}$ per year ${ }^{8}$ ), are generally benign, hypervascularized and tend to invade the temporal bone during their growth, being diagnosed on average 5 years after the onset of symptoms. Only 1 to $5 \%$ are malignant. ${ }^{5}$

Symptoms are directly related to the site of involvement and infiltration. Glomus jugular tumors represent neoplastic lesions originating from the adventitia of the jugular vein, usually affected by symptoms related to the involvement of low cranial nerves, such as the vagus (X), the accessory (XI) and the hypoglossal (XII). In the variation of the tympanic glomus, the tumors are related to neuroendocrine cells along the Jacobson Nerve - the tympanic branch of the glossopharyngeal nerve that arises from its lower level - conducted by the tympanic membrane, auditory tube and mastoid region; it also carries parasympathetic preganglionic fibers from the lower salivatory nucleus that connect with the optical ganglion - it enters the tympanic cavity through the lower tympanic channel and invests in the tympanic plexus; parasympathetic fibers leave the nervous petrosus minor. A more common initial clinical presentation in $\sim 75 \%$ of patients is the presence of pulsatile tinnitus, followed by deafness in the conduction and vertigo. In the third anatomotopographic variant of this tumor, the vagal glomus originates from nonchromaffinous paraganglionic cells associated along the Arnold nerve - the auricular branch of the vagus nerve or the mastoid branch - formed by a branch of the upper vagal ganglion (jugular) and an angle inferior brightness (petrous), ascension through the mastoid canal, in the lateral jugular fossa - leading to the sensitivity of the external auditory canal and the skin of the external ear. Detailed examination through otoscopy may reveal the presence of tympanic membrane invasion.

Von Hippel-Lindau (VHL) disease is a rare pathology ( $\sim 1$ in every 36.000 cases $^{9}$ ), with autosomal dominant transmission and age-related penetrance ( $>90 \%$ until 60 years old). ${ }^{10}$ It is caused by mutations in the tumor suppressor gene $V H L$ that encodes the pVHL protein, responsible for regulating hypoxia-induced genes through ubiquitination and subsequent degradation of the $\alpha$ subunits of hypoxia-induced (HIF1 $\alpha$, HIF2 $\alpha$ and HIF3 $\alpha$ ). This loss of function of the protein leads to the clinical manifestation of the disease, characterized by the presence of several benign and malignant tumors, 


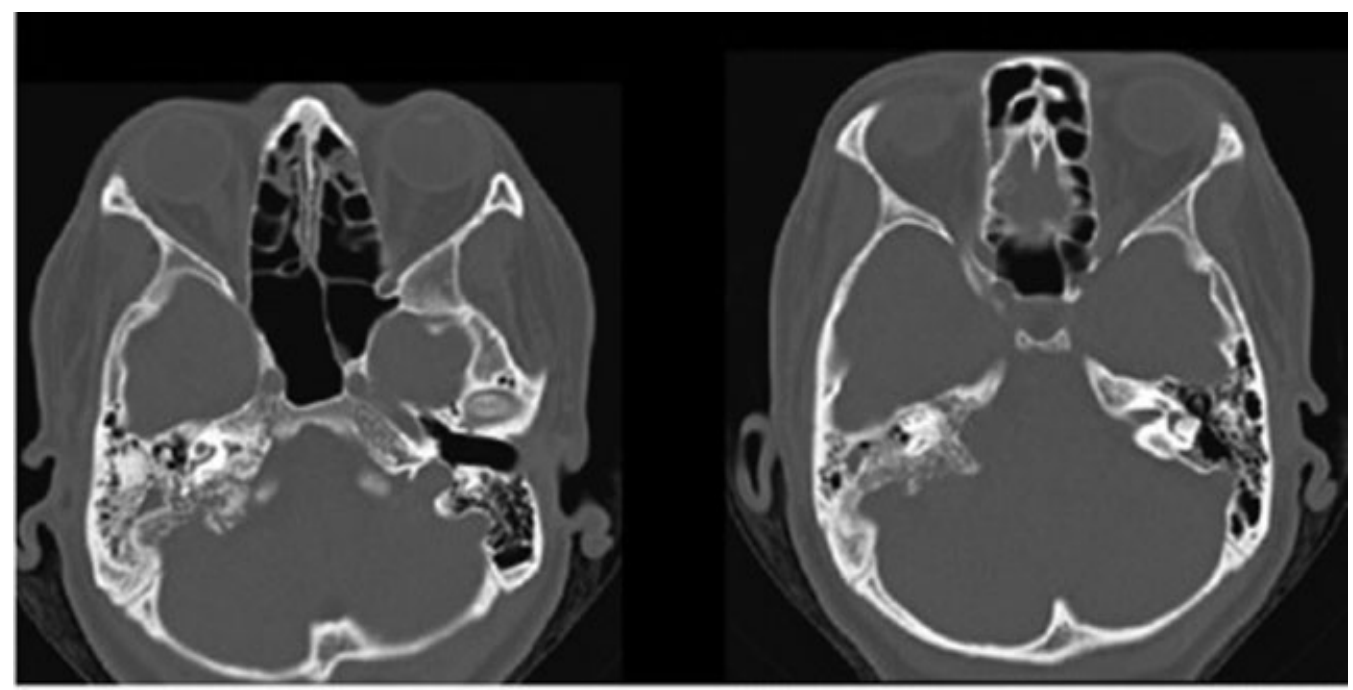

Fig. 1 Skull tomography axial sections in the bone window: parajugular portion extension and the right temporal inner ear bone with a "ground moth" pattern.

such as retinal angiomas, hemangioblastomas of the central nervous system (CNS) and renal cells carcinoma.

The authors present a case report of JF PGL operated on a patient with Von Hippel-Lindau Disease (VHL) diagnosed at the Neurosurgery Service of the Hospital Heliópolis, São Paulo, state of São Paulo, Brazil, in 2018.

\section{Case Report}

M.S., 21 years old, female, with a history of progressive hearing loss on the right side for 4 years. This symptom worsened in the previous 6 months before hospitalization, when she also started presenting subjective vertigo and right hemicranial headache, compression of mild intensity without alarm signs that denote intracranial hypertension. She was admitted to the Neurosurgery Service of the Heliópolis
Hospital and after image studies a probable right glomus jugular tumor was diagnosed.

She has a history of multiple pancreatic cysts, with a familial history of Von Hippel-Lindau disease in a first-degree relative (mother), with a genetic test confirming the disease.

Submitted to a physical examination, the patient presented with anacusis on the right side. There was no change in the other components of the neurological examination. In the complementary investigation, audiometry was performed with evidence of sensorineural anacusis in the right ear. At the cranial computed tomography (CT) scan, extensive erosion of the parajugular portion and inner ear of the right temporal bone was observed with a moth-eaten pattern (-Fig. 1). At magnetic resonance imaging (MRI), the heterogeneous enhanced sign, like salt and pepper, was characterized in an enlarged solid / cystic lesion of $3.6 \times 3.3 \times 3.3 \mathrm{~cm}$,

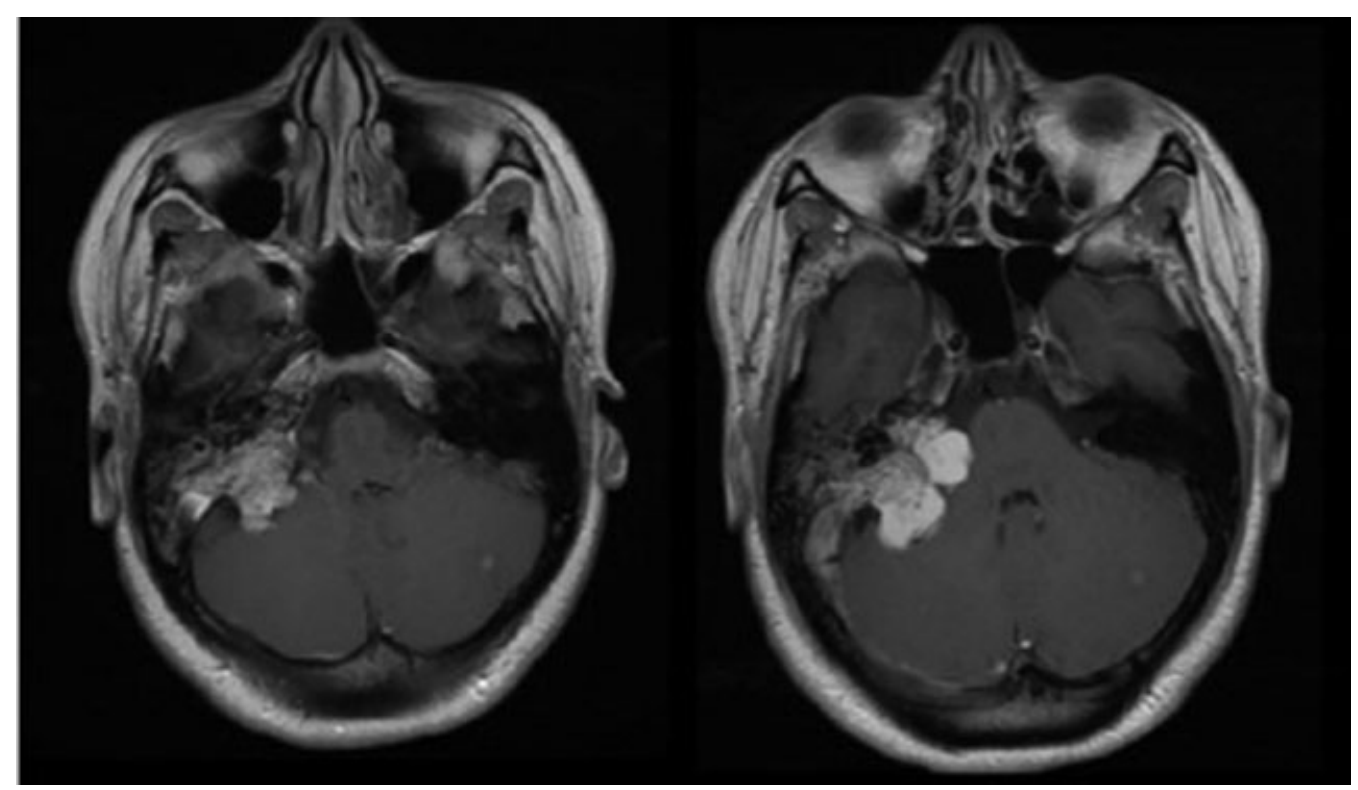

Fig. 2 Brain with contrast axial magnetic resonance imaging sections, showing a heterogeneous "salt and pepper" enhancement pattern in an expansive solid-cystic lesion. 


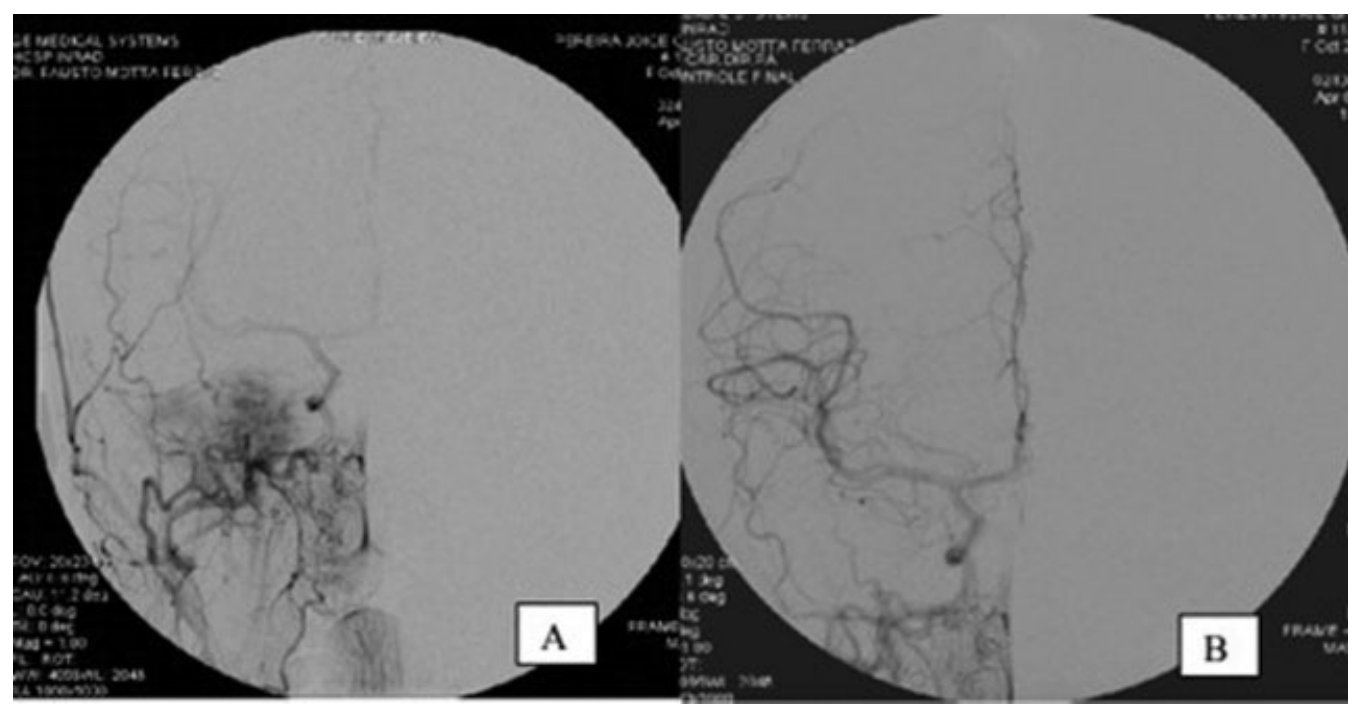

Fig. 3 Cerebral angiography in anteroposterior: A- tumor blush with tympanic branch predominant irrigation of right ascending pharyngeal artery; B- post embolization control of ascending pharyngeal artery with evident reduction in tumor vascularization.

multissepted, centered on the right jugular fossa with extension to the cistern of the cerebellopontine angle, invading the internal auditory canal, extending superiorly to the cerebellar tent, with meningeal infiltration of the middle fossa and causing compression of the middle cerebellar peduncle (-Fig. 2).

The most relevant laboratory tests before surgery are serum and urinary catecholamines, as well as urinary levels of vanillmandelic acid and urinary metanephrines, to determine the possibility of tumor neuroendocrine secretion. Unfortunately, preoperative values are not available.

Due to intense tumor vascularization, diagnostic cerebral angiography was performed with subsequent preoperative embolization, obtaining a satisfactory reduction in tumor vascularization; the examination revealed tumor blush with predominant irrigation of the tympanic branch of the right ascending pharyngeal artery, with contributions from the petrosal branch of the middle meningeal artery and of the stylomastoid branch of the occipital artery (-Fig. 3 ). The bulb of the right jugular vein was occluded and the cerebral venous drainage redirected to the left transverse, sigmoid and jugular sinus.

After 48 hours of embolization, microsurgical resection of the lesion was performed by the combined pre- and retrosigmoid route with intraoperative monitoring of the cranial nerves and the aid of an ultrasonic aspirator, obtaining a satisfactory excision without complications. At first, cervical dissection was performed to obtain proximal vascular control; subsequently, the presigmoid access was initiated by mastoidectomy, obtaining resection of the tumoral mastoid portion and the invasive portion in the jugular bulb. In the second stage, a lateral suboccipital craniotomy was performed for retrosigmoid access; by this route, a satisfactory resection of the lesion was obtained in the topography of the JF, which extended to the antigen-presenting cell (APC).

The histological aspect of the lesion is typical of a paraganglioma with polygonal epithelioid cells of abundant and clear cytoplasm arranged in small lobes (alveolar arrangement) called "zellbalen." The diagnosis by immunohistochemistry showed positivity for AE1-AE3, synaptophysin and protein S100.

The outcome of the patient was uneventful in the postoperative period, maintaining the neurological status and the previous right hearing loss, without any additional deficits.

\section{Discussion}

Paragangliomas (PGLs) can be sporadic or arise in the context of a familial syndrome. Currently, 40 to $60 \%$ are derived from germline mutations. ${ }^{6,11}$ Several familial hereditary syndromes are associated with PGLs, including VHL disease. Von HippelLindau disease is an autosomal dominant tumor predisposition syndrome, characterized by multiple benign and malignant tumors of the central nervous system (CNS), kidneys, pancreas, adrenal glands, and paraganglia. ${ }^{12}$ The clinical diagnosis of VHL is defined, ${ }^{13}$ among other criteria, by an individual with a family history in the presence of a tumor characteristic of the syndrome, such as retinal hemangioblastoma or CNS, renal clear cell carcinoma, pheochromocytoma (PCC)/paraganglioma or endolymphatic sac tumor.

In a cohort study, 109 patients were identified with VHL. The mean age at the time of VHL diagnosis was 29 years old. Family history was available in 95 patients (87\%); 62 (65\%) of these patients (53\%) had first-degree relatives with VHL. Among these patients, 3 (3\%) had paraganglioma: 2 of the inner ear and 1 along the juxtarenal aortic. ${ }^{12}$ In a similar study from the Mayo Clinic PCC/PGL registry, 610 patients were identified with various forms and locations of PCC/PGL. From those, 81 surgical patients were included in the study, of which 19 had VHL. ${ }^{14}$

The patient reported in the present case had VHL disease, as she had a mother with a previous diagnosis (hemangioblastoma, pancreatic neuroendocrine tumor and positive genetic test for mutation in the VHL gene), in addition to presenting a CNS PGL and pancreatic cysts.

Paragangliomas have a peak incidence between the ages of 30 and 50 years old; ${ }^{7}$ however, when associated with 
hereditary syndromes, they tend to occur a decade earlier ${ }^{15}$; women are 3 to 6 times more affected than men and are diagnosed on average 5 years after the onset of symptoms. The PGLs (corresponding to $3 \%$ of total paragangliomas), called parasympathetic PGLs, are $50 \%$ of genetic etiology. ${ }^{16}$ Such data are consistent with the case presented: female patient with intracranial paraganglioma, with hereditary syndrome (VHL), aged 21 years old and with symptoms lasting $\sim 4$ years until her diagnosis.

According to Jackson et al., almost all patients will experience pulsatile tinnitus and hearing loss, either conductive or sensorineural. For Jackson et al. the hearing loss is usually conductive, but a sensorineural component may occur if the cochlea is involved. Besides that, other common symptoms include vertigo and unsteadines. ${ }^{17}$ According to Katsuta et al. and Rothon et al., ${ }^{18,19}$ what we can understand is that the tumor extended to the posterior cranial fossa, through the intracranial orifice of the JF, and to the cerebellopontine angle, through the round window and the internal acoustic meatus. This pathophysiological and anatomical data of the tumor behavior is confirmed by the MRI scan, showing that the tumor has an epicenter in the right jugular fossa and extends to the ipsilateral cerebellar point, invading the internal auditory canal. This anatomical configuration, therefore, is similar to tumors of the JF (paragangliomas, schwannomas and meningiomas).

Al-Mefty et al. describes that CT, MRI, and angiographic findings were necessary diagnostic tools for PGLs. Angiographic studies were critical for assessing the appropriateness of preoperative embolization after the blood supply of the tumor had been demonstrated. ${ }^{20}$ The typical imaging pattern of PGLs (an MRI scan with heterogeneous signal in T1 and T2 with gadolinium-enhanced in salt and pepper sign and a CT scan showing extensive erosion of the parajugular portion of the temporal bone) was the same as the one presented in this case. In the classification by Jackson et al.,21 the tumor presented was confirmed as type II ( $\mathbf{-}$ Table $\mathbf{1}$ ).

Digital angiography was performed in the case report patient and preoperative embolization to reduce bleeding during surgery was necessary, ${ }^{5,19}$ being performed 48 hours before the described surgery. According to Ramina et al., preoperative embolization is very useful to reduce bleeding and surgical time. For Jackson et al., embolization, such as radio-

Table 1 Glasscock-Jackson classification for glomus tumors in the Jugular foramen

\begin{tabular}{|l|l|}
\hline I & $\begin{array}{l}\text { Tumor involving jugular bulb, middle ear and } \\
\text { mastoid }\end{array}$ \\
\hline II & $\begin{array}{l}\text { Tumor extending below the internal acoustic } \\
\text { meatus; may present intracranial extension }\end{array}$ \\
\hline III & $\begin{array}{l}\text { Tumor extending to the petrous apex; may pres- } \\
\text { ent intracranial extension }\end{array}$ \\
\hline IV & $\begin{array}{l}\text { Tumor extending beyond the petrous apex to the } \\
\text { infratemporal clivus or infratemporal fossa; may } \\
\text { present intracranial extension }\end{array}$ \\
\hline
\end{tabular}

Source: Brain and Spine tumors - Primary and secondary. Jugular Foramen Paragangliomas. ISBN 978-1- 78984-158-9. therapy techniques, are arguably adjunctive, but should not be considered curative. For most authors, surgical treatment is considered the definitive treatment for head and neck PGLs that can offer immediate and complete tumor elimination. ${ }^{17,22-24}$

At immunohistochemistry, ${ }^{25}$ a specific neuron enolase is positive in neoplastic cells, deriving from neural crest paraganglia. The S-100 protein is characteristically positive in sustaining cells, which surround the lobes of tumor cells. The $5 \%$ of $\mathrm{K}_{\mathrm{i}}-67$, found in this case is typical of progressive growth cells, such as PGLs. Both synaptophysin and chromogranin are associated with neurotransmitter vesicles and are positive in the cytoplasm of neoplastic cells, consistent with the neuroendocrine nature of this type of tumor. Butz JJ et al. it relates the increase in tumor size in any type of syndrome PPC/PGL with higher concentrations of catecholamines and catecholamine metabolites measured preoperatively. ${ }^{12}$

Intraoperative electrophysiological monitoring is essential to prevent nerve damage, to locate their trajectory inside and around the tumor and to estimate the postoperative functional prognosis. ${ }^{26,27}$ Following the rationale exposed in the literature and seeking the integrity of the neurological function of the asymptomatic patient in relation to the other cranial nerves (except VIII), the surgery was performed with monitoring of the III to XII cranial nerves, allowing a resection guided by neurophysiology, which contributed to the excellence of the postoperative result of maintaining the function of all the cranial nerves, except the previously compromised.

Regarding access to the jugular foramen, according to Katsuta et al. and Rothon et al., ${ }^{18,19}$ there are three possible groups: (1) lateral group, approaches through the mastoid; (2) posterior group, approaches through the posterior cranial fossa through the retrosigmoid access and its variants; and (3) anterior group, centered on the tympanic bone. The choice of the most appropriate access requires an understanding of the nature as well as of the extent of the injury. The combination of two or three accesses may be necessary, either at different times or in a single surgical intervention. ${ }^{28}$

The most used surgical technique involves a mastoidectomy and access to the infratemporal fossa to resect the tumor. ${ }^{17,22-24}$ Radical resection of large PGLs of the jugular foramen with intracranial extension is difficult, and for this reason a multidisciplinary skull base approach offers the best chance of total removal with preservation of lower cranial nerves, vessels and of the brainstem. ${ }^{22}$

In the case reported, a combined access was used to approach the lesion: an access from the lateral group - whose basic element is mastoidectomy - combined with an access from the posterior group (via retrosigmoid). Prior to the mastoidectomy, cervical dissection was performed to provide proximal control of the great vessels (both the internal carotid and the internal jugular vein). Immediately after the mastoidectomy, with extensive infra-labyrinthic drainage, access was allowed to the upper jugular bulb and to the tumor portion at this level.

The second stage of the surgery was a lateral suboccipital craniotomy for retrosigmoid access; according to Katsuta et al. and Rothon et $\mathrm{al}^{18,19}$ lesions located predominantly in the intradural space can be resected through the retrosigmoid access. This provides a broader view of the nerves entering the 
JF and also has practically the same window obtained at the retrolabyrinthine route as well as the minimal mastoidectomy - with the advantage of having an obtained view in less surgical time - moreover, it exposes the cisterns of the cerebellopontine angle and the intracranial segment of the cranial nerves that cross the jugular foramen, the hypoglossal canal and the internal acoustic meatus as well.

\section{Conclusion}

Paragangliomas associated with genetic familial syndromes with VHL disease are rare entities that deserve scientific notification. This tumor resection is possible from precise clinical evaluation and preoperative exams. Complications can occur during and after the surgery and, therefore, we must be adequately prepared for their treatment. The use of embolization in the preoperative period may considerably reduce bleeding during surgery. Once again, we truly believe that experience is essential for its effective treatment.

Note

Institution where the Case Report was held: Hospital

Heliópolis, São Paulo, state of São Paulo, Brazil

\section{Conflict of Interests}

The authors have no conflict of interests to declare.

\section{References}

1 Guild SR. A hitherto unrecognized structure: the glomus jugularis in man. Abstracted. Anat Rec Suppl 1941;2(79):28

2 Gulya AJ. The glomus tumor and its biology. Laryngoscope 1993; 103(11 Pt 2):(Suppl 60):7-15

3 Barnes L, Eveson JW, Reichart P, Sidransky D. Tumours of the paraganglionic system: Introduction. World Health Organization Classification of Tumours Pathology and Genetics of Head and Neck Tumours

4 Guinto G, Kageyama M, Trujillo-Luarca VH, Abdo M, Ruiz-Than A, Romero-Rangel A. Nonglomic tumors of the jugular foramen: differential diagnosis and prognostic implications. World Neurosurg 2014;82(06):1283-1290

5 Gottfried ON, Liu JK, Couldwell WT. Comparison of radiosurgery and conventional surgery for the treatment of glomus jugulare tumors. Neurosurg Focus 2004;17(02):E4

6 Martins R, Bugalho MJ. Paragangliomas/Pheochromocytomas: clinically oriented genetic testing. Int J Endocrinol 2014;2014:794187

7 Boedeker CC, Neumann HP, Maier W, Bausch B, Schipper J, Ridder GJ. Malignant head and neck paragangliomas in SDHB mutation carriers. Otolaryngol Head Neck Surg 2007;137(01):126-129

8 Jansen JC, van den Berg R, Kuiper A, van der Mey AG, Zwinderman $\mathrm{AH}$, Cornelisse CJ. Estimation of growth rate in patients with head and neck paragangliomas influences the treatment proposal. Cancer 2000;88(12):2811-2816

9 Poulsen ML, Budtz-Jørgensen E, Bisgaard ML. Surveillance in von Hippel-Lindau disease (vHL). Clin Genet 2010;77(01):49-59
10 Ferreira MA, Vilaverde J. A genética dos feocromocitomas e paragangliomas. Rev Port Endocrinol Diabetes Metab. 2014; 9:29-35

11 Pillai S, Gopalan V, Smith RA, Lam AK. Updates on the genetics and the clinical impacts on phaeochromocytoma and paraganglioma in the new era. Crit Rev Oncol Hematol 2016;100:190-208

12 BAGHAI Mercedeh. et al. Pheochromocytomas and paragangliomas in von Hippel-Lindau disease: a role for laparoscopic and cortical-sparing surgery. Archives of Surgery, v. 137, n. 6682-6892002

13 Nielsen SM, Rhodes L, Blanco I, et al. Von Hippel-Lindau Disease: Genetics and Role of Genetic Counseling in a Multiple Neoplasia Syndrome. J Clin Oncol 2016;34(18):2172-2181

14 Butz JJ, Yan Q, McKenzie TJ, et al. Perioperative outcomes of syndromic paraganglioma and pheochromocytoma resection in patients with von Hippel-Lindau disease, multiple endocrine neoplasia type 2, or neurofibromatosis type 1 . Surgery 2017; 162(06):1259-1269. Doi: 10.1016/j.surg.2017.08.002

15 Eisenhofer G, Timmers HJ, Lenders JW, et al. Age at diagnosis of pheochromocytoma differs according to catecholamine phenotype and tumor location. J Clin Endocrinol Metab 2011;96(02): 375-384

16 Lin D, Carty S, Young WF. Paragangliomas: Epidemiology, clinical presentation, diagnosis, and histology. Available at: http://www. uptodate.com

17 Jackson CG, Glasscock ME III, Harris PF. Glomus Tumors. Diagnosis, classification, and management of large lesions. Arch Otolaryngol 1982;108(07):401-410

18 Katsuta T, Rhoton AL Jr, Matsushima T. The jugular foramen: microsurgical anatomy and operative approaches. Neurosurgery 1997;41(01):149-201, discussion 201-202

19 Rhoton AL Jr. Jugular foramen. Neurosurgery 2000;47(03): S267-S285

20 Al-Mefty O, Teixeira A. Complex tumors of the glomus jugulare: criteria, treatment, and outcome. J Neurosurg 2002;97(06): 1356-1366. Doi: 10.3171/jns.2002.97.6.1356

21 Jackson CG, Glasscock ME III, Nissen AJ, Schwaber MK. Glomus tumor surgery: the approach, results, and problems. Otolaryngol Clin North Am 1982;15(04):897-916

22 RAMINA Ricardo. et al. Jugular foramen tumors: diagnosis and treatment. Neurosurgical Focus, v. 17, n. 231-402004

23 Jackson CG, Harris PF, Glasscock ME III, et al. Diagnosis and management of paragangliomas of the skull base. Am J Surg 1990;159(04):389-393

24 Suárez C, Rodrigo JP, Bödeker CC, et al. Jugular and vagal paragangliomas: Systematic study of management with surgery and radiotherapy. Head Neck 2013;35(08):1195-1204

25 Dichiro G, Fisher RL, Nelson KB. The jugular foramen. J Neurosurg 1964;21:447-460

26 Leonetti JP, Brackmann DE, Prass RL. Improved preservation of facial nerve function in the infratemporal approach to the skull base. Otolaryngol Head Neck Surg 1989;101(01):74-78

27 Fisch U, Fagan P, Valavanis A. The infratemporal fossa approach for the lateral skull base. Otolaryngol Clin North Am 1984;17(03): 513-552

28 Samii M, Bini W. Surgical strategy for jugular foramen tumors. In: Sekhar LN, Janecka IP (eds). Surgery of Cranial Base Tumors. New York: Raven Press; 1993:379-387 